\title{
Tubular Adenomatous Polyp in a Colon Interposition: A Case Report and Review of Literature
}

\author{
Abraham Yacoub $^{\mathrm{a}}$, Leslie Bank ${ }^{\mathrm{b}, \mathrm{d}}$, Jagmohan S. Sidhu ${ }^{\mathrm{c}}$
}

\begin{abstract}
Esophagectomy with colon interposition is a technique used for the replacement of a diseased esophagus. Since segments of the colon are used in this procedure, clinicians must be aware that a variety of pathologies can arise from colonic interposition. Therefore, patients who undergo this procedure and are due for a screening or surveillance colonoscopy must also get a screening or surveillance upper endoscopy to examine the interposed colon. We report a case of a 59-year-old male who had a history of Barrett's esophagus with high grade dysplasia successfully treated with colon interposition. Upper endoscopy showed a tubular adenomatous polyp of the colonic segment.
\end{abstract}

Keywords: Colon interposition; Left colon; Colorectal cancer; Colon polyps

\section{Introduction}

Colon interposition surgery has been utilized post esophagectomy with success [1]. The colon has a number of characteristics that make it an excellent option for esophageal replacement. Advantages include long length, acid resistance, and typically excellent blood supply [1]. Adenoma and adenocarcinoma can appear as a late complication in colonic tissue grafts used to substitute the esophagus [2]. Early detection and treatment

Manuscript accepted for publication November 13, 2014

aUnited Health Services Wilson Medical Center, Department of Internal Medicine, 33-57 Harrison St, Johnson City, NY, USA

bUnited Health Services Wilson Medical Center, Upstate Medical University, Binghamton Gastroenterology Associates, 40 Mitchell Ave, Binghamton, NY 13903, USA

'Anatomic Pathology \& Clinical Pathology, Hematology, United Health Services Wilson Medical Center, 33-57 Harrison St, Johnson City, NY, USA

${ }^{\mathrm{d} C}$ Corresponding Author: Leslie Bank, United Health Services Wilson Medical Center, Upstate Medical University, Binghamton Gastroenterology Associates, 40 Mitchell Ave, Binghamton, NY 13903, USA.

Email: leslie.bank@gmail.com

doi: http://dx.doi.org/10.14740/jmc1990w can decrease morbidity and mortality [3]. At our institution, we present a case of an adenomatous polyp found in a patient with colonic interposition 6 years after surgery for Barrett's esophagus with high grade dysplasia.

\section{Case Report}

A 59-year-old white male with a history of Barrett's esophagus diagnosed 24 years ago, underwent esophagectomy with colonic transposition (6 years ago) for high grade dysplasia. He came into our clinic complaining of a "stricture like sensation" in his throat, difficulty eating, and weight loss. His symptoms started a few months back and were getting progressively worse. There were no alleviating or aggravating factors. The patient also complained of fatigue, anorexia, a sense of early satiety, and diarrhea.

His past medical history includes diverticulitis, hypoglycemia, and Barrett's esophagus. His surgical history includes esophagectomy with colonic transposition using the sigmoid colon, a previous tonsillectomy, and a colonoscopy in 2010. The patient smokes half a pack of cigarettes a day, and consumes 12 bottles of beer every week. He consumes one pot of regular coffee every day. He denies any illicit drug use. There is no family history of Barrett's esophagus or colon cancer.

An esophagogastroduodenoscopy (EGD) procedure was

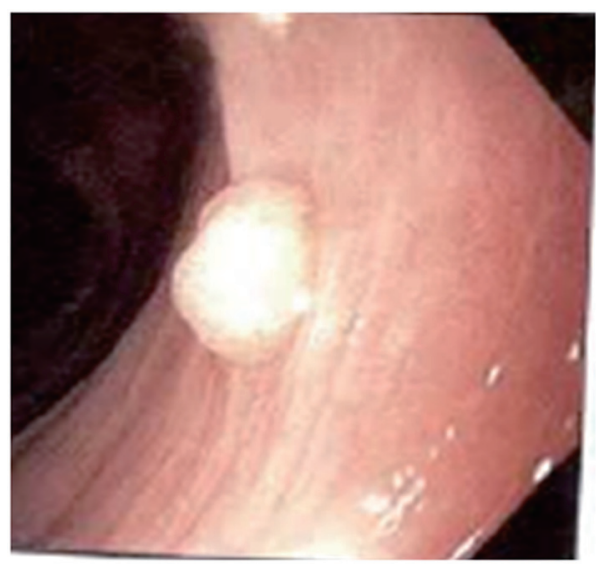

Figure 1. Olympus video gastroscope shows a $0.8 \mathrm{~cm}$ polyp in the mid portion of the interposed colon. 


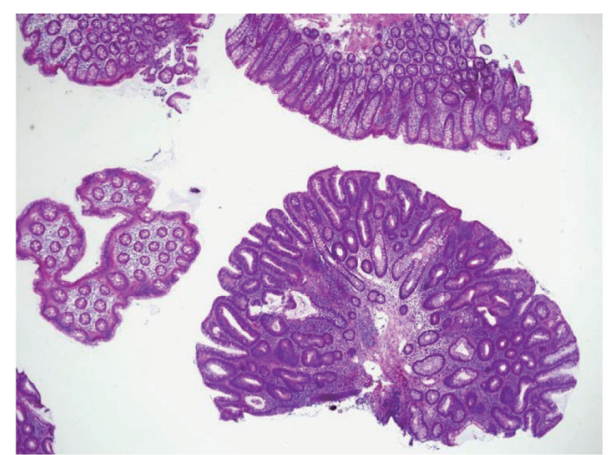

Figure 2. Hematoxylin and eosin (H\&E) of tubular adenomatous polyp at $\times 40$ magnification. Right lower piece of colonic mucosa shows a polyp containing tubular structures. The tubules are composed of columnar cells with hyperchromatic and basally located nuclei.

performed using an Olympus video gastroscope. This showed a $0.8 \mathrm{~cm}$ polyp (Fig. 1) arising from the mid portion of the interposed colon. The polyp was completely removed with multiple bites of a jumbo biopsy forceps.

The pathology report of the polyp revealed a tubular adenoma (Fig. 2, Fig. 3). The gastroesophageal junction biopsy showed benign colonic mucosal segments, squamocolumnar anastomosis with intense chronic inflammation and reactive epithelial change. No Barrett's metaplasia was seen.

\section{Discussion}

The use of long segments of the colon, either for replacement or bypass of all or part of the thoracic esophagus, was introduced independently by Kelling and Vulliet in 1911 [4]. Since then, the colon has emerged as a well-functioning and durable esophageal substitute when the stomach cannot be used [4-6].

To date, gastric pull-up is the most frequent reconstruction after esophagectomy. Yildirim et al demonstrated that the overall satisfaction was superior in patients undergoing colonic interposition [7]. However, other studies done by Hashesh et al suggested that gastric pull-up was more preferable and easier to perform [8]. Colonic interposition had increased morbidity, compared with gastric transposition. However the overall mortality and survival were similar to those for gastric transposition [9].

Esophagectomy with colon interposition has been used in benign and malignant diseases of the esophagus such as strictures [10] and cancer [11]. This procedure may cause surgical complications such as anastomotic leakage and sepsis due to colon necrosis [5], delayed fibrosis [12], esophagocolonic anastomotic stricture [13], dysphagia [14], Claude BernardHorner syndrome [15], and aorto-colonic fistula [16].

Advantages include long length, acid resistance, typically excellent blood supply, and the potential for a wide gastric resection margin in patients with cancers of the gastroesophageal junction [17]. Peters et al showed that replacement of the esophagus with the colon can be successful in over $80 \%$ of patients screened by angiographic criteria [18]. The left colon is the most common segment used in colon interposition due

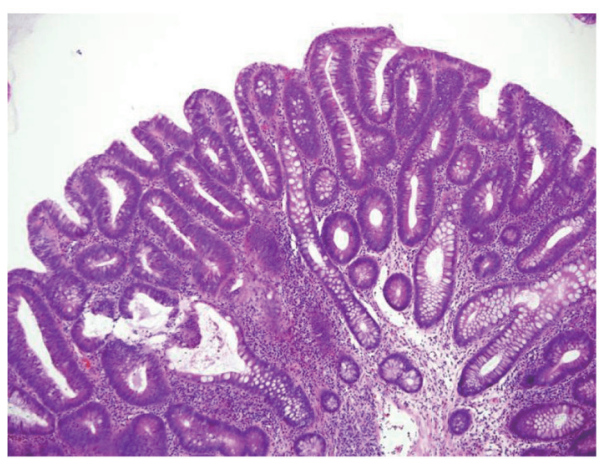

Figure 3. Hematoxylin and eosin (H\&E) of tubular adenomatous polyp at $\times 100$ magnification which shows tubules that are composed of columnar cells with hyperchromatic and basally located nuclei.

to its good blood supply [19]. Absolute contraindications to colon interposition are the presence of intrinsic colon disease such as inflammatory bowel disease, malignancy, or inadequate arterial blood supply from peripheral vascular disease [20].

Screening or surveillance for colorectal cancer is a crucial preventative measure. In addition to a screening colonoscopy, clinicians should perform a screening upper endoscopy in patients with a history of colon interposition as pathology may arise from the colonic segment. The patient in our case should have had a screening EGD in addition to screening colonoscopy in 2010. This case serves as a reminder of the importance of colon interposition screening. Furthermore, in the review of literature (Table 1) [14, 21-38], 15 out of 22 patients have developed adenocarcinoma in the grafted interposed colon. This could have been prevented if the patients had regular EGD screening or surveillance follow-up. Our patient was fortunate enough to be diagnosed with tubular adenoma prior to the development of advanced cancer. According to the European Society of Gastrointestinal Endoscopy (ESGE) guidelines, our patient is considered a "low risk group" based on the histology and the size of the polyp removed from the interposed colon [39]. The current recommendation for surveillance and screening after polypectomy is between 5 and 10 years [40]. It is also suggested that patients who have polyps in the interposed colon should undergo colonoscopy to rule out synchronous lesions [21]. Since there are no guidelines available for screening and surveillance of the grafted colon interposition, we recommended that our patient should have a repeat EGD and colonoscopy surveillance in 3 years.

\section{Conclusion}

Esophagectomy with colon interposition is a successful treatment for the diseased esophagus. The emphasis of our case is to continue screening and surveillance for colon cancer where ever colonic tissue is found. Since there are no current guidelines for the management of screening or surveillance of colon interposition, we suggest that clinicians who encounter these patients must always screen the interposed colonic graft at the same time that the patient has a colon cancer screening. 

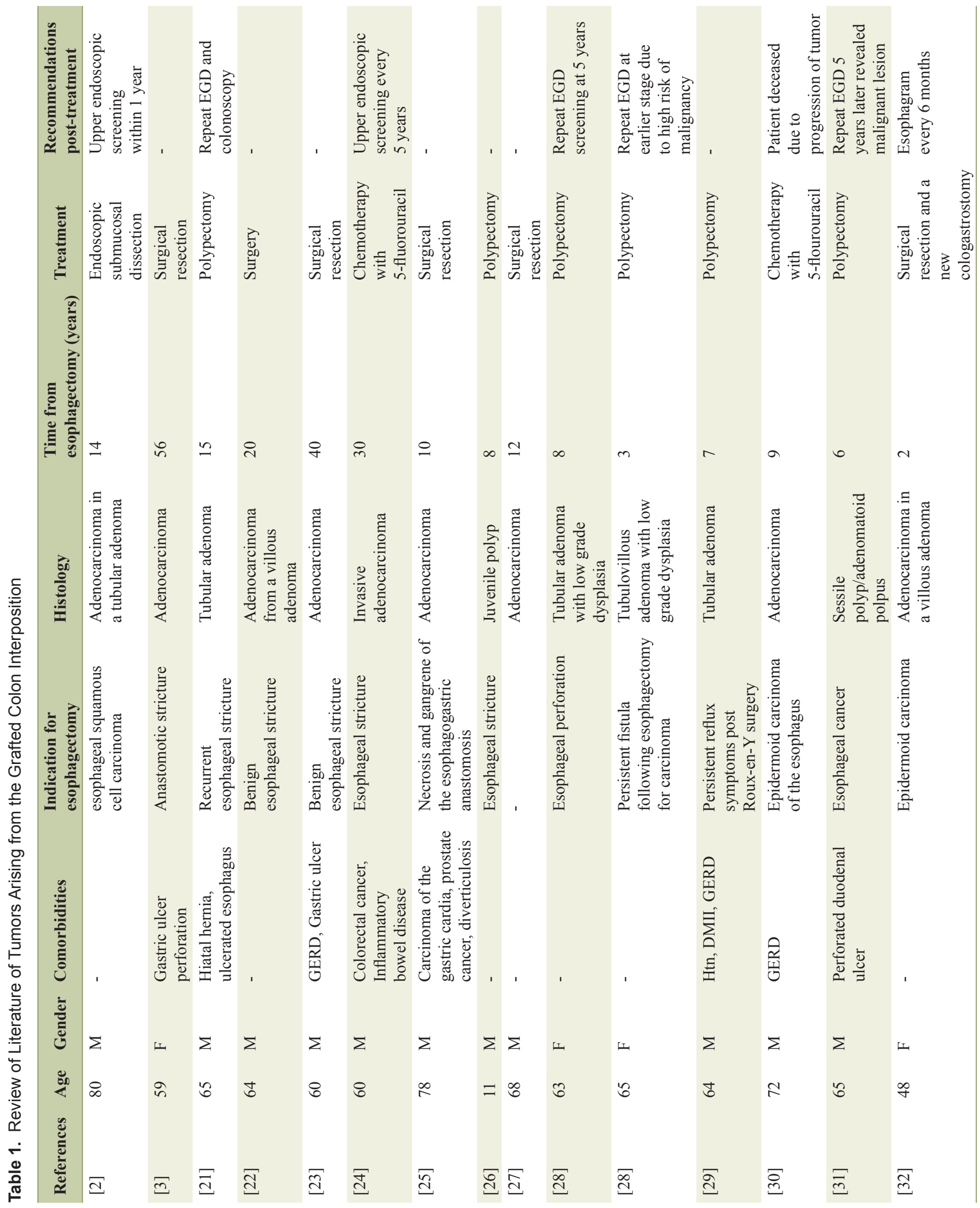


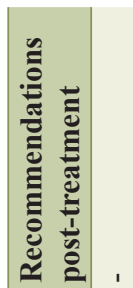

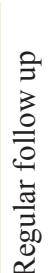

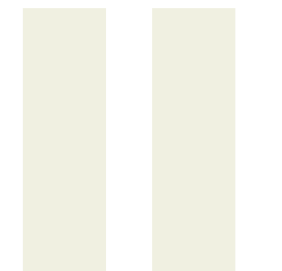

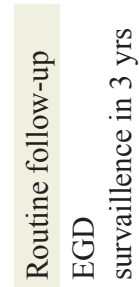
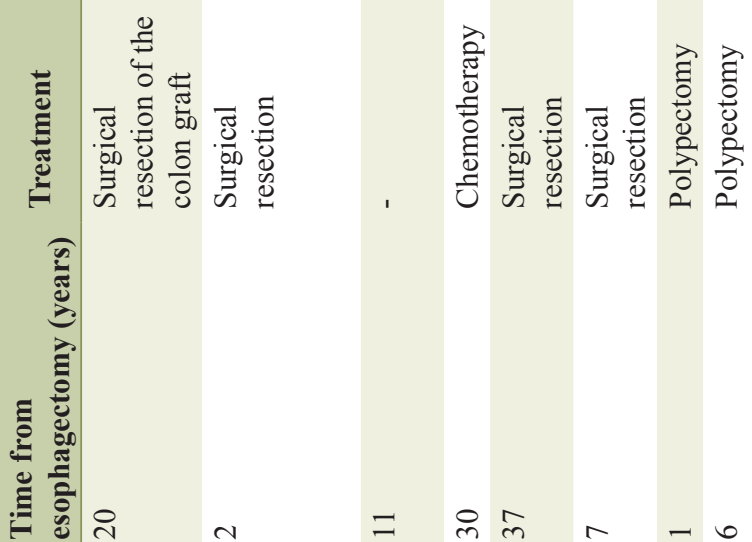

จิ

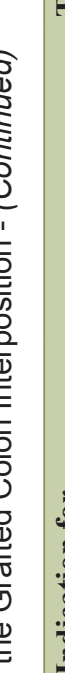

은
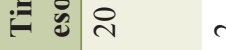

$$
=\text { in } n-6
$$
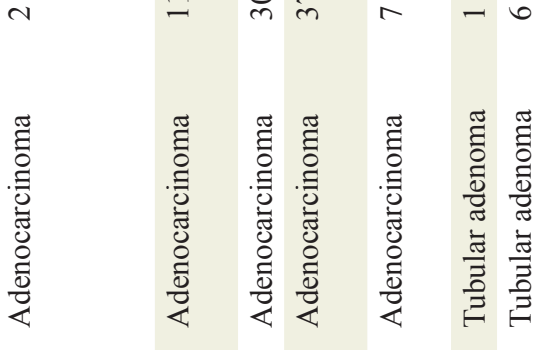

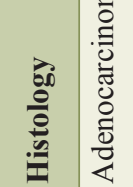

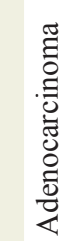
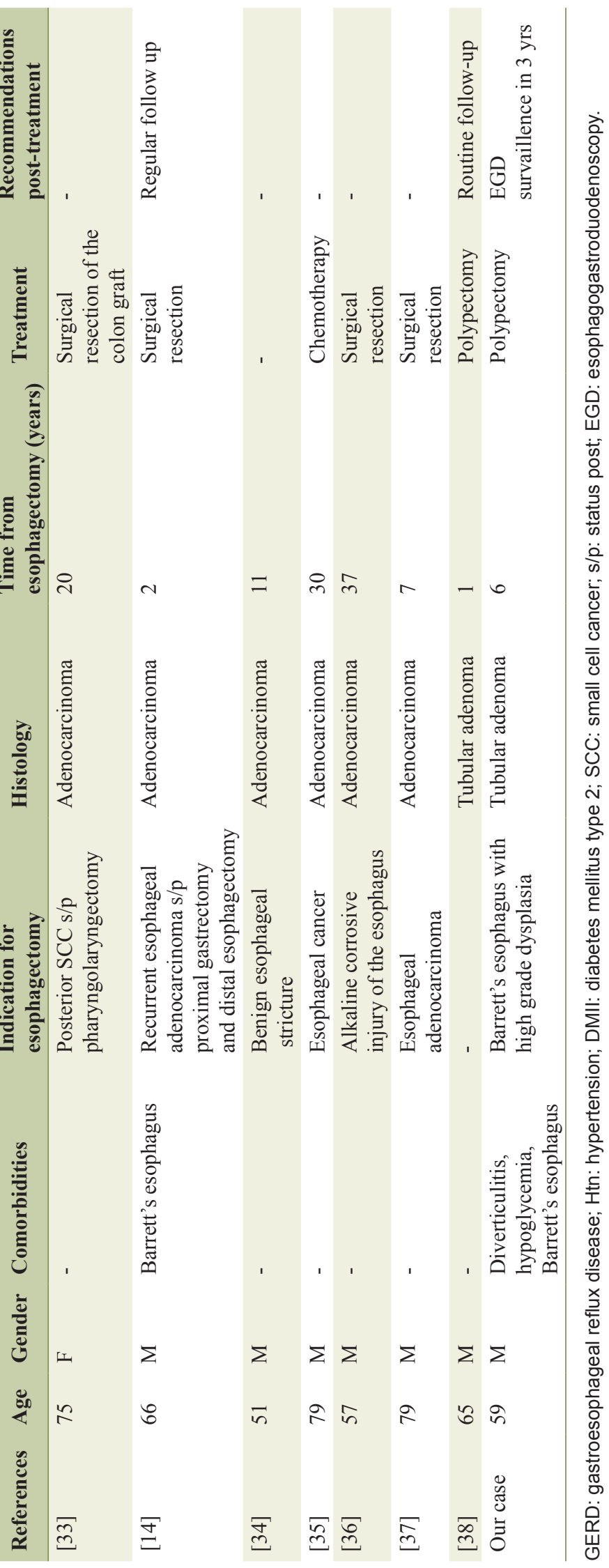


\section{Disclosure}

The authors have no funding or conflicts of interest to disclose.

\section{References}

1. Thomas PA, Gilardoni A, Trousse D, D'Journo XB, Avaro JP, Doddoli C, Giudicelli R, et al. Colon interposition for oesophageal replacement. Multimed Man Cardiothorac Surg. 2009;2009(603):mmcts 2007002956.

2. Bando H, Ikematsu H, Fu KI, Oono Y, Kojima T, Minashi $\mathrm{K}$, Yano T, et al. A laterally-spreading tumor in a colonic interposition treated by endoscopic submucosal dissection. World J Gastroenterol. 2010;16(3):392-394.

3. Grunner S, Gilshtein H, Kakiashvili E, Kluger Y. Adenocarcinoma in colonic interposition. Case Rep Oncol. 2013;6(1):186-188.

4. DeMeester TR, Johansson KE, Franze I, Eypasch E, Lu CT, McGill JE, Zaninotto G. Indications, surgical technique, and long-term functional results of colon interposition or bypass. Ann Surg. 1988;208(4):460-474.

5. Oida T, Mimatsu K, Kano H, Kawasaki A, Kuboi Y, Fukino N, Kida K, et al. Anterior vs. posterior mediastinal routes in colon interposition after esophagectomy. Hepatogastroenterology. 2012;59(118):1832-1834.

6. Peng L, Han YT, Wang X, Xiao WG, Fang Q, Li Q, Chen LH. [Application of colonic interposition in the digestive tract reconstruction after esophagectomy]. Zhonghua Wei Chang Wai Ke Za Zhi. 2011;14(9):695-698.

7. Yildirim S, Koksal H, Celayir F, Erdem L, Oner M, Baykan A. Colonic interposition vs. gastric pull-up after total esophagectomy. J Gastrointest Surg. 2004;8(6):675-678.

8. Hashesh A, Ismail K, Metwally MF, et al. Gastric Pullup Versus Colon Interposition in Treatment of Corrosive Esophageal Stricture. Egyptian Journal of Surgery. 2003;22(3):283-288.

9. Davis PA, Law S, Wong J. Colonic interposition after esophagectomy for cancer. Arch Surg. 2003;138(3):303308.

10. Negre J, Markkula H. Esophagectomy and colon interposition for benign esophageal stricture. Acta Chir Scand. 1984;150(8):639-642.

11. Saeki H, Morita M, Harada N, Egashira A, Oki E, Uchiyama H, Ohga T, et al. Esophageal replacement by colon interposition with microvascular surgery for patients with thoracic esophageal cancer: the utility of superdrainage. Dis Esophagus. 2013;26(1):50-56.

12. Harvey JG, Kettlewell MG. An unusual complication of colonic interposition for oesophageal replacement. Thorax. 1979;34(3):408-409.

13. Stone MM, Fonkalsrud EW, Mahour GH, Weitzman JJ, Takiff H. Esophageal replacement with colon interposition in children. Ann Surg. 1986;203(4):346-351.

14. Spitali C, De Vogelaere K, Delvaux G. Dysphagia after colon interposition graft for esophageal carcinoma. Case Rep Pathol. 2012;2012:738205.

15. Katsanos KH, Markoula S, Christodoulou DK, et al.
Claude Bernard-Horner syndrome associated with colonic interposition grafting after esophagectomy. Annals of Gatroenterology. 2006;19(1):77-80.

16. Debras B, Kanane O, Enon B, Robert M. Aorto-colonic fistula as a late complication of colon interposition for oesophageal atresia. Eur J Pediatr Surg. 1996;6(5):310311.

17. DeMeester SR. Colon interposition following esophagectomy. Dis Esophagus. 2001;14(3-4):169-172.

18. Peters JH, Kronson JW, Katz M, DeMeester TR. Arterial anatomic considerations in colon interposition for esophageal replacement. Arch Surg. 1995;130(8):858-862; discussion 862-853.

19. Furst H, Hartl WH, Lohe F, Schildberg FW. Colon interposition for esophageal replacement: an alternative technique based on the use of the right colon. Ann Surg. 2000;231(2):173-178.

20. DeMeester TR, Kauer WKH. Esophageal Reconstruction: The colon as an esophageal substitute. Diseases of the Esophagus. 1995;8:20-29.

21. Kovacs BJ, Griffin RA, Chen YK. Synchronous adenomas in a colonic interposition graft and the native colon. Am J Gastroenterol. 1997;92(12):2303-2304.

22. Houghton AD, Jourdan M, McColl I. Dukes A carcinoma after colonic interposition for oesophageal stricture. Gut. 1989;30(6):880-881.

23. Shersher DD, Hong E, Warren W, Penfield Faber L, Liptay MJ. Adenocarcinoma in a 40-year-old colonic interposition treated with Ivor Lewis esophagectomy and esophagogastric anastomosis. Ann Thorac Surg. 2011;92(6):e113-114.

24. Aryal MR, Mainali NR, Jalota L, Altomare JF. Advanced adenocarcinoma in a colonic interposition segment. BMJ Case Rep. 2013;2013.

25. Goyal M, Bang DH, Cohen LE. Adenocarcinoma arising in interposed colon: report of a case. Dis Colon Rectum. 2000;43(4):555-558.

26. Del Rosario MA, Croffie JM, Rescorla FJ, Hartman GE. Juvenile polyp in esophageal colon interposition. J Pediatr Surg. 1998;33(9):1418-1419.

27. Theile DE, Smithers BM, Strong RW, Windsor CJ. Primary adenocarcinoma in a colonic oesophageal segment. Aust N Z J Surg. 1991;61(12):953-955.

28. Ramage L, Davies AR, Deguara J, Mason RC. Polyps arising in a colonic interposition graft: instigation of endoscopic graft surveillance may be required. Surgeon. 2012;10(5):304-305.

29. Altomare JF, Komar MJ. A tubular adenoma arising in a colonic interposition. J Clin Gastroenterol. 2006;40(8):765-766.

30. Haerr RW, Higgins EM, Seymore CH, el-Mahdi AM. Adenocarcinoma arising in a colonic interposition following resection of squamous cell esophageal cancer. Cancer. 1987;60(9):2304-2307.

31. Altorjay A, Kiss J, Voros A, Szanto I, Bohak A. Malignant tumor developed in colon-esophagus. Hepatogastroenterology. 1995;42(6):797-799.

32. Goldsmith HS, Beattie EJ, Jr. Malignant villous tumor in a colon bypass. Ann Surg. 1968;167(1):98-100. 
33. Lee SJ, Koay CB, Thompson H, Nicolaides AR, Das Gupta AR. Adenocarcinoma arising in an oesophageal colonic interposition graft. J Laryngol Otol. 1994;108(1):80-83.

34. Licata AA, Fecanin P, Glowitz R. Metastatic adenocarcinoma from oesophageal colonic interposition. Lancet. 1978;1(8058):285.

35. Liau CT, Hsueh S, Yeow KM. Primary adenocarcinoma arising in esophageal colon interposition: report of a case. Hepatogastroenterology. 2004;51(57):748-749.

36. Hsieh YS, Huang KM, Chen TJ, Chou YH, OuYang CM. Metachronous adenocarcinoma occurring at an esophageal colon graft. J Formos Med Assoc. 2005;104(6):436440.

37. Roos D, Busch OR, van Lanschot JJ. [Primary colon carcinoma in a colon interposition graft after oesophageal resection]. Ned Tijdschr Geneeskd. 2007;151(38):21112114.

38. Szanto I, Kiss J, Vamosi-Nagy I, Voros A. Endoscopic polypectomy in the segment of colon used for oesophageal replacement. Endoscopy. 1981;13(3):134.

39. Hassan C, Quintero E, Dumonceau JM, Regula J, Brandao C, Chaussade S, Dekker E, et al. Post-polypectomy colonoscopy surveillance: European Society of Gastrointestinal Endoscopy (ESGE) Guideline. Endoscopy. 2013;45(10):842-851.

40. Lieberman DA, Rex DK, Winawer SJ, Giardiello FM, Johnson DA, Levin TR. Guidelines for colonoscopy surveillance after screening and polypectomy: a consensus update by the US Multi-Society Task Force on Colorectal Cancer. Gastroenterology. 2012;143(3):844-857. 